IJLR: International Journal of Law Recontruction

Volume 4, Number 2, September 2020

DOI : http://dx.doi.org/10.26532/ijlr.v4i2.10976

\title{
THE HANDLING OF HUMAN TRAFFICKING WITH MAIL ORDER BRIDE MODE IN WEST KALIMANTAN
}

\author{
Yenny AS \\ Faculty of law, Panca Bhakti University \\ yenny.upb@gmail.com \\ Anita Yuliastini \\ Faculty of law, Panca Bhakti University \\ anitayuliastinj1979@gmail.com \\ Rini Setiawati \\ Faculty of law, Panca Bhakti University \\ rini090366@gmail.com
}

\begin{abstract}
Trafficking especially women and children in West Kalimantan, is still vulnerable in various modes, including through order bride. Factors that influence the trafficking include poverty, lack of education, limited employment, patriarchal culture, and weak law enforcement as well as mechanisms and coordination of handling trafficking. This article will explore the issue of trafficking with the mail order bride mode by revealing the problem of what factors are obstacles in law enforcement handling the crime of trafficking in persons with the order bride mode. This article will explore the issue of handling the trafficking with the order bride mode by revealing the problem of what factors are obstacles in law enforcement handling the crime of trafficking in persons with the mail order bride mode. Through the socio-legal research method with a qualitative approach, the research results are obtained that the obstacles faced in handling criminal acts of trafficking with the mail order bride mode are still weak cooperation and coordination between relevant agencies and law enforcement officials, especially these crimes occur in transnational networks.
\end{abstract}

Keywords: Trafficking, mail order brides, legal handling

\section{A. INTRODUCTION}

Human Trafficking is a violation of human rights and a global problem ${ }^{1}$. Historically, trafficking in persons can be said to be slavery and also violates human rights ${ }^{2}$. Human Trafficking is also a major international issue in almost twenty countries ${ }^{3}$. Human trafficking is one of the five

1 Meredith Scannell et al., Human Trafficking: How Nurses Can Make a Difference, Journal of Forensic Nursing, Volume 14, no. 2, 2018, Page. 117-21,

2 A R Prakoso and P A Nurmalinda, Kebijakan Hukum Terhadap Tindak Pidana Perdagangan Orang, Seminar Nasional Hukum, 2018, Page. 1-24,

3 Atharva Vyas, Child Trafficking, International Journal of Trend in Scientific Research and Development, Volume 2, no. Issue-5, 2018, Page.1121-26, 
biggest crimes in the world that must be overcome because of its impact not only on economic aspects, but also on political, cultural, and humanitarian aspects. ${ }^{4}$. There are more than $3,000,000$ trafficked women, including children. ${ }^{5}$. Trafficking of women is one aspect of transnational migration, and it is also one of the most complex global issues ${ }^{6}$. Musdah Mulia revealed that trafficking of women and children in Indonesia generally starts with migration activities, and globalization has facilitated the migration process from one country to another ${ }^{7}$

The UN defines human trafficking as the recruitment, transportation, transfer, harboring, or receipt of persons by improper means (such as force, abduction, persons by improper means (such as force, abduction, fraud, or coercion) for an improper purpose including fraud, or coercion) for an improper purpose including forced labor or sexual exploitation. ${ }^{8}$

Human Trafficking, especially women and children from Indonesia to overseas has become rampant as widespread sending of women laborers abroad. Many cases of fraud committed by syndicates where to prospective migrant workers are promised jobs, but they are trafficked into forced prostitution, even illegal migrant workers expelled from Malaysia become targets of trafficking syndicates. ${ }^{9}$. Supriyadi Widodo stated trafficking is an extraordinary crime, this crime is organized, and transnational so it can be categorized as a transnational organized crime. ${ }^{10}$

In West Kalimantan, trafficking takes a variety of forms, including trafficking by migrating victims to Taiwan, Hong Kong in the form of contract marriages, and then victims plunged into the valley of prostitution and forced labor ${ }^{11}$

One mode that occurs in West Kalimantan is the mail order bride. The brokers are looking for beautiful women in Singkawang, especially Chinese women to be married to a foreign male, Taiwan, Hong Kong, and Singapore. As a result of marrying the order, not a few women who

4 Deypend Tommy Sibuea, Pemberantasan Perdagangan Orang Melalui Instrumen Hukum Nasional Dan Hukum Internasional DI Indonesia, Cendekia Hukum, Volume 3, no. 2, 2018, Page.228-40,

5 James A. Levine, Mental Health Issues in Survivors of Sex Trafficking, Cogent Medicine, Volume 4, no. 1, 2017, Page.1-13,

6 Sabirin, Perdagangan Perempuan Dengan Dalih Perkawinan, RAHEEMA: Jurnal Studi Gender Dan Anak, 2005, Page.54-62,

7 Rahadi Wasi Bintoro Hj. Siti Muflichah, TRAFFICKING: Suatu Studi Tentang Perdagangan Perempuan Dari Aspek Sosial, Budaya Dan Ekonomi Di Kabupaten Banyumas, Dinamika Hukum, Volume 9, no. 1, 2009, Page.125-34,

8 Vyas, "Child Trafficking."

9 Yenny AS et al., Legal Protection for Human Trafficking Victim, Especially Women and Children in West Kalimantan, International Journal of Multi Discipline Science (IJ-MDS), Volume 1, no. 1, 2018, Page.42,

10 Sabirin, Perdagangan Perempuan Dengan Dalih Perkawinan, RAHEEMA: Jurnal Studi Gender Dan Anak, 2005, Page.54-62,

11 Abu Hanifah, Perdagangan Perempuan Dan Anak; Kajian Faktor Penyebab Dan Alternatif Pencegahannya., Penelitian Dan Pengembangan Kesejahteraan Sosial, Volume 13, no. 02 2008, Page.46-60 
become displaced in other countries and deceived, until there were employed as commercial sex workers or others ${ }^{12}$.

Order bride is a modern manifestation of arranged marriages and can be a case of trafficking when a girl marries under pressure from her family (especially if she is under 18 years old) and ends up in slavery or exploitative conditions. The phenomenon of mail order brides in Indonesia seems to be particularly prevalent in Indonesian Indonesians of Chinese descent in West Kalimantan Province (although some cases of East Java are reported to have taken place), with prospective husbands coming from Taiwan $^{13}$.

The factors causing trafficking with the mail order bride mode are more influenced by poverty and unavailability of jobs so that women who live in Singkawang contract marriage to change their standard of living. The next factor is the low level of education so often they are forced to accept exploratory work, this poverty factor is caused by the mindset of Chinese parents in Singkawang, West Kalimantan that high schools are not important, and this mindset makes people of Chinese descent Singkawang does not have high education and cannot work in the formal sector. Another factor is the level of consumerism, women in Singkawang want to have the luxury and good goods so that they are recognized in their environment, and the last factor is ethnicity, their parents indoctrinate their children by saying that people of Chinese descent in Singkawang are one descent with Taiwanese people. This condition is used by brokers/marriage brokers as targets for prospective brides to hunt for potential brides to easily capture their victims to make a profit ${ }^{14}$.

Cultural factor marriage in ethnic Chinese communities with the term "photo wedding" is also one of the modes of human trafficking in the form of order brides. Mail order bride mode as a form of human trafficking, namely through marriage between women (Amoy) of West Kalimantan and foreign citizens, such as Taiwan, Hong Kong, Singapore, through the mail order bride service, where men from foreign nationals or through these candidates come to Indonesia to look for and choose brides (generally women of ethnic Chinese, because in the culture and traditions of Chinese marriage, a legal marriage is marked by a photo together with the bride and groom, so it does not have to fulfill the administrative requirements of the corresponding first and the parties other). Most of the victims of the bride mail order service are the poor. For one bride, the brokers will get around Rp. 10-15 million, from the cost of the wedding package issued in the amount of Rp. 60-70 million. The issue that deserves attention is from the marriage the reality is not recorded as required in the legislation, regarding the legal requirements of marriage, especially regarding the recording of mixed marriages between citizens conducted. As a result, if

12 Elly Triana, Pola Komunikasi Interpersonal Korban Trafficking Pengantin Pesanan Di Singkawang Kalimantan Barat, Volume 7, no. April, 2009, Page.29-37,

13 Siti Rochmiyatun, "Perdagangan Perempuan Perspektfi Yuridis, An Nisa'A, Volume 8, no. 1, 2013, Page.82-101,

14 Elly Triana, Pola Komunikasi Interpersonal Korban Trafficking Pengantin Pesanan Di Singkawang Kalimantan Barat, Volume 7, no. April, 2009, Page.29-37, 
problems arise from marriage, women, who come from Indonesia, become victims who will have difficulty accessing protection. ${ }^{15}$

Responding to the mail order bride mode in the crime of trafficking that occurred in West Kalimantan, it is necessary to study how to handle law enforcement, because the tendency of these acts to occur across national borders and also constituted organized crimes. Based on this situation, the purpose of this study is to reveal the factors that become constraints in law enforcement to handling the human trafficking with order bride mode in West Kalimantan. The problem to be discussed in this study is factors are obstacles in law enforcement handling the crime of trafficking with the mail order bride mode in West Kalimantan.

\section{B. RESEARCH METHOD}

This legal research uses the sociological method (socio-legal research) with a qualitative approach. A qualitative (naturalistic) approach is essentially observing people in their environment, interacting with them, trying to understand their language and interpretation of the world around them. The research specifications used are descriptive, meaning in giving a description of the phenomena that are carried out in accordance with the research method. The facts are illustrated with an interpretation from the emic and etic perspective one after another and continue.

\section{DISCUSSION}

\section{Overview of Criminal Acts of Trafficking with Order Bride Mode in West Kalimantan}

Human trafficking, especially of women and children originating from Indonesia to abroad, is rife along with the ease of cross-country flows through the land, water and air and the economic pressures of society. West Kalimantan Province, one of which has a specific geographical condition that immediately borders with foreign countries (East Malaysia) through the official entrance points of the Entikong and Tebedu Post Border (PLB) and there are no less than 50 (fifty) pathways (unofficial) which can be traversed to enter and exit to and from the territory of East Malaysia. The geographical location of the Province of West Kalimantan encourages the increasing practices of human trafficking abroad. The involvement of international criminal trafficking syndicate networks through Transnational Post Border (transnational) is inseparable from the strategic position, where human traffic flow does not experience difficulties in and out. This makes human trafficking traffic easier ${ }^{16}$

Cases of Trafficking in Persons that occur in West Kalimantan generally have forms including labor exploitation, sexual exploitation, and child exploitation. slavery and mail order brides.

15 Henny Damaryanti, Yenny AS, Perlindungan Hukum Terhadap Perempuan Dan Anak Korban Tindak Pidana Perdagangan Orang Melalui Modus Pengantin Pesanan, Volume 1, no. 1, 2020, Page.1-8,

16 Yenny AS. 
Singkawang City, West Kalimantan is known by the nickname City of the Thousand Temples. But, the city which is predominantly inhabited by ethnic Chinese also has a culture of photo wedding or mail order bride from Singkawang. This culture is usually experienced by Amoys, as Chinese women, who marry a man from Taiwan. ${ }^{17}$

Likewise, trafficking in the form of mail order brides takes place in West Kalimantan and is more common in Singkawang City. The reality of the order brides originated from Amoy (a Chinese woman) who came from Singkawang City in a vulnerable condition because of poverty and low education levels persuaded by brokers by showing several videos of Chinese women from Indonesia (generally also from Singkawang) who had been married Men are generally from Taiwan, their lives are happy and the economic condition of their families has changed with the house in the village that has been repaired because of a shipment from Amoy who was married earlier. The persuasion was not only given to Amoy or the woman, but also to her parents so that the parents and Amoy were tempted to change their destinies economically. Then Amoy (a Chinese woman) was brought/recruited and/or transferred by a broker to Pontianak to pass his passport and then the broker played the role of a "makcomblang (matchmaker)" as the Chinese people's marriage culture had enough matchmakers and photo marriages, Amoy (a Chinese woman) was mated with a man who came from Taiwan and was further sent to Taiwan.

The fact is that the marriage that took place between Amoy (a Chinese woman) and Taiwanese man is only a marriage made according to Chinese customs so that the marriage is not recorded as a statutory provision as a mixed marriage between nationalities. This condition is certainly no protection and legal certainty for Amoy (a Chinese woman) earlier. And the reality is also the matchmaker or scalper who brought Amoy (a Chinese woman) after the marriage was traditionally held and brought together the Taiwanese pris earlier, he was rewarded between 15-20 million Rupiah, so this fact shows the practice of trafficking in persons with the bride order mode. The reality is that after arriving in Taiwan, there was an Amoy whose life could run as a normal household, but ironically there was also an Amoy (a Chinese woman) who became a victim, because she was treated as a slave to work on her husband's own estate, without the same treatment as a husband and wife, there are also prostituted by her husband, even there are also other problems, where the identity of her passport is hidden by her husband, even has been changed, identity as citizens of Taiwan so that citizenship status is lost, and there are also those who have children so that women as victims did not have access to have the right to his child because of his child's citizenship status. This happens because marriages are not recorded so they do not get legal protection.

17 Triana, Elly. Pola Komunikasi Interpersonal Korban Trafficking Pengantin Pesanan Di Singkawang Kalimantan Barat, Volume 7, April, 2009, Page.29-37. 
This problem was revealed when the woman returned to Indonesia and reported her case to the Police, as data revealed in the West Kalimantan Regional Police from 2017 to 2019 recorded 18 cases of trafficking in persons using the mail order bride mode.

However, from this case, the handling has only reached the investigation stage, because it is difficult to ensnare the perpetrators who are in Taiwan, and there are also brokers who have been named suspects, but also have difficulty in disclosure, due to verification. The reality of the rampant cases of trafficking (trafficking) in West Kalimantan, including through the bride order mode, the most important and crucial thing is the importance of mechanisms and cooperation in handling them, especially efforts to provide legal protection to victims of human trafficking, who are vulnerable to women and children.

\section{Law Enforcement of Human Trafficking}

Trafficking is a transnational crime that is cross-border / crossregional in nature, in this case, law enforcement officials are obliged to cooperate with various parties in handling it. ${ }^{18}$

Sanofta DJ Ginting in his journal entitled "Criminal Law Policy in tackling human trafficking crimes", that law enforcement in Indonesia in handling trafficking in persons does not always run smoothly, because there are several factors that influence it including its own legal factors, law enforcement factors, facility or facility factors, community factors, and cultural factors. Legal reform has a very strong relationship with politics, therefore, the requirement of a criminal law policy in dealing with trafficking in persons in the process of making it until its institutionalization is carried out by political institutions, which are institutions that have power in society ${ }^{19}$

Law enforcement against the crime of trafficking in Indonesia is still not optimal where we can see this from the news in the media, both in print and electronic media, so many cases of trafficking in persons are identified as trafficking victims, but to ensnare traffickers is very difficult because from the modus operandi it turns out that the culprit is more than one person and is corporate in nature and is an organized crime. ${ }^{20}$

The process of law enforcement or institutionalization in handling trafficking in persons is carried out through a policy of application / judicial or the stage of application of criminal law by law enforcement officials starting from the police, prosecutors, and courts ${ }^{21}$

18 Cahya Wulandari et al., Tindak Pidana Perdagangan Orang ( Human Trafficking ) Khususnya Terhadap Perempuan Dan Anak: Suatu Permasalahan Dan Penanganannya Di Kota Semarang, Yustisia, Edisi 90, 2014, Page.15-26,

19 Prakoso and Nurmalinda, Kebijakan Hukum Terhadap Tindak Pidana Perdagangan Orang."

20 Herlien C.Kamea, Penegakan Hukum Pidana Terhadap Kejahatan Perdagangan Orang Menurut Undang-Undang Nomor 21 Tahun 2007, Lex Crimen, Volume V, no. 2 (2016, Page.126-32,

21 Prakoso and Nurmalinda, Kebijakan Hukum Terhadap Tindak Pidana Perdagangan Orang. 
In analyzing how law enforcement is in handling trafficking in persons through the mail order bride mode, L.M.Friedman's view of the operation of the legal system can be used as a starting point for analysis. According to Lawrence M. Friedman, for the purposes of analysis, the legal system that operates can be regarded as something that contains three components. The first component is the structural component, which is the parts that move in a mechanism. The second component is the substance, that is, the actual results issued by the legal system. The structure and substance are actually what is generally called the legal system. The third component is in the form of a legal culture which is a human attitude towards law and the legal-belief system, the value of thought, and expectations. In other words, the legal culture of the social mood and social forces that determine how the law is used, avoided or misused.

Based on this view, the Government of Indonesia should adopt policies in an effort to optimize the law in providing protection for victims of trafficking, especially women and children. In the legal order in force in Indonesia, the efforts made in handling this trafficking are to formulate a legislation policy by issuing Law Number 21 the Year 2007 concerning Eradication of Criminal Acts on Trafficking in Persons.

This law has also formulated the criminalization of various forms of human trafficking, as stated in the provisions of Articles 2 to 27. The various forms that can be qualified as criminal acts of trafficking in persons include:

a. recruit, transport, collect, transfer, transfer or accept someone with the threat of violence, use of force, abduction, confiscation, fraud, abuse of power or a vulnerable position, entrapment of debt or pay or benefit even if the approval of the person holding control over another person, for the purpose of exploiting that person.

b. push people into the territory of the Republic of Indonesia with the intent to be exploited in Indonesia or other countries.

c. Take Indonesian citizens outside the territory of the Republic of Indonesia with the intent to be exploited outside the territory of the Republic of Indonesia

d. adopting a child by promising something to give something with the intention to be exploited

e. send the child in or out of the country in any way that results in the child being exploited.

f. Conducting a state that abuses power resulting in the occurrence of criminal acts of trafficking in persons.

g. Anyone who moves others, assists or conducts experiments, or plans / engages in bad dealings to commit criminal acts of trafficking in persons.

h. use or make use of victims of trafficking in persons by engaging in sexual intercourse or other obscene acts with victims of trafficking in persons, employ victims of trafficking in persons to carry out 
exploitation practices, or take advantage of the proceeds of the Criminal Act of Trafficking in Persons

i. Criminalization of corporations that commit Trafficking in Persons

j. submit or insert false information on state documents or other documents or falsify state documents to facilitate the occurrence of Trafficking in Persons

k. provide false testimony, submit fake evidence or fake evidence, or influence witnesses in an unlawful manner in the Court of Trafficking in Persons

I. carry out physical attacks on witnesses or officials at the trial in the case of the Criminal Act of Trafficking in Persons

m. intentionally prevent, hinder or frustrate directly or indirectly investigations, prosecutions, and hearings in court hearings against suspects, defendants, or witnesses in cases of Criminal Trafficking in Persons

n. assist in the escape of the perpetrators of Trafficking in Persons

o. inform the witness or victim's identity, even though he has been told that the identity of the witness or victim must be kept confidential.

\section{Constraints in Law Enforcement in the Handling of Human Trafficking with Mail Order Bride Mode in West Kalimantan}

The more organized crime of human trafficking, the more troublesome the government is to provide protection for victims because crime becomes transnational, structured and systematic ${ }^{22}$. While the victims are those who suffer physical, psychological and material losses when trafficking occurs ${ }^{23}$

As an illustration of the cases that occurred in West Kalimantan, during 2017-2019 there were 18 cases of trafficking with the bride order mode, and in 2019 the cases that occurred were recorded as unresolved, as revealed in the following table :

Recapitulation Of Criminal Case That Handled By Sub Directorate N Special Criminal Investigation Regional Police West Kalimantan On 2019

\begin{tabular}{|c|c|c|c|c|c|c|c|c|c|c|c|c|c|c|c|c|c|}
\hline \multirow{3}{*}{ No } & \multirow{3}{*}{ Case Type } & \multicolumn{5}{|c|}{ Total } & \multicolumn{6}{|c|}{ Settlement } & \multicolumn{4}{|c|}{ Handling Process } & \multirow{3}{*}{$\begin{array}{l}\text { Explane } \\
\text { tion }\end{array}$} \\
\hline & & \multirow[t]{2}{*}{ Case } & \multicolumn{2}{|c|}{ Victim } & \multicolumn{2}{|c|}{ Suspect } & \multirow[t]{2}{*}{ Stage 2} & \multicolumn{3}{|c|}{ Termination of Investigation } & \multirow[t]{2}{*}{ Delegate } & \multirow[t]{2}{*}{ Total } & \multirow{2}{*}{$\begin{array}{c}\text { Stage } \\
1\end{array}$} & \multirow{2}{*}{$\begin{array}{l}\text { Investi } \\
\text { gation } \\
\text { (1) }\end{array}$} & \multirow{2}{*}{$\begin{array}{l}\text { Investi } \\
\text { gation } \\
\text { (2) }\end{array}$} & \multirow[t]{2}{*}{ Total } & \\
\hline & & & Adult & Child & Adult & Child & & RevocatioN & $\begin{array}{c}\text { NotCriminal } \\
\text { Act }\end{array}$ & Diversi & & & & & & & \\
\hline$\theta$ & 2 & 3 & 4 & 5 & 6 & 7 & 8 & 9 & 10 & 11 & 12 & 13 & 14 & 15 & 16 & 17 & 18 \\
\hline & $\begin{array}{l}\text { Human Trafficking with } \\
\text { Order Bride Mode }\end{array}$ & 3 & 3 & & 3 & & 1 & & & & & & & & 2 & & \\
\hline
\end{tabular}

The data in the case above shows that the handling has only reached the investigation stage, because it is difficult to ensnare the

22 Alfan Alfian, Upaya Perlindungan Hukum Terhadap Tindak Pidana Perdagangan Orang, Fiat Justisia Jurnal Ilmu Hukum, Volume 9, no. 3, 2015, Page.331-39

23 Rani Hendriana, The Prevention of Victim Precipitation in the Criminal Acts of Fornication and Coition Against Children, SHS Web of Conferences, 54, 2018, Page.04001, 
perpetrators who are in Taiwan, and there are also brokers who are accused, but also experience difficulties in disclosure, because of the evidence. The reality is that handling trafficking in persons, especially women and children is not an easy job and can be done in a short time, but it is a long and ongoing process. Although it has been accommodated in Law Number 21 the Year 2007 concerning the Eradication of the Criminal Act of Trafficking in Persons, Law Enforcement Officials in reality still find obstacles in their law enforcement, because this crime is a transnational crime, several policies are needed in handling it at the regional level. , especially in efforts to prevent it.

European legal instruments on human trafficking have encouraged countries to handle victims of trafficking services, by establishing victim service facilities ${ }^{24}$. Therefore, in supporting prevention efforts, success is highly dependent on the commitment of government administrators at various levels, the participation of community organizations / NGOs and the community itself, and highly dependent also on law enforcement efforts.

Efforts have been made and in particular policies in dealing with trafficking in persons especially women and children in West Kalimantan have been established;

a. Regional Regulation Number 7 of 2007 concerning Prevention and Eradication of Trafficking in Persons, Especially Women and Children;

b. West Kalimantan Governor Regulation Number 5 the Year 2010 concerning Amendment to Governor Regulation Number 86 the Year 2006 concerning Regional Action Plans for the Elimination of Trafficking of Women and Children

c. West Kalimantan Governor Regulation Number 10 the Year 2017 concerning Amendment to Governor Regulation Number 11 the Year 2016 concerning the One-Stop Integrated Service Placement and Protection of Indonesian Workers in West Kalimantan Province

d. West Kalimantan Governor Regulation No. 53 of 2017 concerning Regional Action Plans for the Protection and Empowerment of Women and Children in Social Conflict in West Kalimantan Province 2017-2021;

e. The decision of the Governor of West Kalimantan Number 270/2009 concerning Amendment to Governor Regulation No. 262/2006 concerning the Establishment of an Integrated Service Center for the Empowerment of Women and Children;

f. Decree of the Governor of West Kalimantan No. 178/2008 concerning the Formation of a Coordination Team for the Prevention, Placement, and Protection of Troubled Indonesian Workers Abroad;

g. Decree of the Governor of West Kalimantan Number 289 of 2006 concerning the Establishment of the Task Force (Task Force) and the

24 Johanna Niemi and Jussi Aaltonen, Tackling Trafficking by Targeting Sex Buyers: Can It Work?, Violence Against Women, 23, no. 10, 2017, Page. 1228-48, 
Secretariat of the Implementing Task Force. Placement and Protection of Troubled Indonesian Workers Abroad in West Kalimantan Province.

However, reality shows that cases of trafficking in persons are still rife even though various policy measures have been set by the Government. This is due to human trafficking with the bride order mode as a syndicate of transnational crime and organized crime, where the perpetrators consist of syndicates starting from the existence of brokers recruiting victims from rural pockets that exploit the poverty alleviation of victims' families, then brokers bring and recruit victims to the syndicated network that is across national borders, with the lure of arranged marriages with Taiwanese men who will change their economic lives so that they reach perpetrators who are already abroad, so that if this case is later revealed it is difficult for the criminal justice system to process its law.

The enactment of legal provisions that provide special protection for women who are victims of trafficking in persons, including through the bride order mode, minimally contains the right of women to get protection from the authorities for behavior that the offender might report to the victim, the right of women to obtain medical, psychological, legal and social assistance especially to restore confidence in him, to treat and heal his injuries, even to be able to undergo legal procedures after receiving information about the procedures he will undergo in the criminal justice process. Besides that, the legal provisions should also contain the right of the victim to obtain compensation for the loss he suffered, both from the government as an organization that is obliged to provide protection to himself, as well as from the perpetrators who have caused extraordinary losses to the victim.

In addition, education and community empowerment efforts are needed as well as women themselves to deal with problems that occur in their own communities. In the end, it all depends on the desire of all citizens to change the conditions that can be more responsive and sensitive in providing protection for women victims of trafficking in persons, through the mail order mode.

\section{CONCLUSION}

There are still any obstacles in law enforcement to handling of human trafficking with the order bride mode in West Kalimantan. These obstacles are the lack of mechanisms and coordination in handling, especially when these crimes occured on across national borders and organized crimes, so that in reality the law enforcement officers have difficulty to act on the offenders who involved in syndicates who are abroad

Overcoming the foregoing efforts are needed to strengthen coordination and cooperation between agencies and law enforcement officers, especially those formed in the Trafficking Task Force in providing 
legal protection for victims of trafficking in persons, both strengthening the resources that handle legal protection for victims of trafficking in persons and improving supporting facilities and infrastructure. Besides that, it is also necessary to optimize minimum service standards in efforts to handle and provide legal protection for victims of trafficking in persons and increase the operational capacity of officers in the Police, especially in the Protection of Women and Children (PPA) units in providing services and legal protection in handling trafficking in persons.

\section{BIBLIOGRAPHY}

\section{Journal :}

Alfian, Alfan. Upaya Perlindungan Hukum Terhadap Tindak Pidana Perdagangan Orang. Fiat Justisia Jurnal Ilmu Hukum, Volume 9, no. 3, 2015, Page. 331-39;

AS, Yenny, Nurfitriawati Nurfitriawati, Klara Dawi, and Sri Ayu Septinawati. Legal Protection for Human Trafficking Victim, Especially Women and Children in West Kalimantan. International Journal of Multi Discipline Science (IJ-MDS), Volume 1, no. 1, 2018, Page.42;

C.Kamea, Herlien. Penegakan Hukum Pidana Terhadap Kejahatan Perdagangan Orang Menurut Undang-Undang Nomor 21 Tahun 2007. Lex Crimen, V, no. 2, 2016, Page.126-32;

Hanifah, Abu. Perdagangan Perempuan Dan Anak; Kajian Faktor Penyebab Dan Alternatif Pencegahannya. Penelitian Dan Pengembangan Kesejahteraan Sosial, Volume.13, no. 02, 2008, Page.46-60;

Hendriana, Rani. The Prevention of Victim Precipitation in the Criminal Acts of Fornication and Coition Against Children. SHS Web of Conferences, 54, 2018, Page.04001;

Hj. Siti Muflichah, Rahadi Wasi Bintoro. TRAFFICKING : Suatu Studi Tentang Perdagangan Perempuan Dari Aspek Sosial, Budaya Dan Ekonomi Di Kabupaten Banyumas. Dinamika Hukum, 9, no. 1, 2009, Page.125-34;

Levine, James A. Mental Health Issues in Survivors of Sex Trafficking. Cogent Medicine, 4, no. 1, 2017, Page.1-13;

Niemi, Johanna, and Jussi Aaltonen. Tackling Trafficking by Targeting Sex Buyers: Can It Work?, Violence Against Women, 23, no. 10, 2017, Page.1228-48;

Prakoso, A R, and P A Nurmalinda. Kebijakan Hukum Terhadap Tindak Pidana Perdagangan Orang. Seminar Nasional Hukum, 2018, Page.1-24;

Sabirin. Perdagangan Perempuan Dengan Dalih Perkawinan. RAHEEMA: Jurnal Studi Gender Dan Anak, 2005, Page.54-62; 
Scannell, Meredith, Andrea E. MacDonald, Amanda Berger, and Nichole Boyer. Human Trafficking: How Nurses Can Make a Difference. Journal of Forensic Nursing, 14, no. 2, 2018, Page.117-21;

Sibuea, Deypend Tommy. Pemberantasan Perdagangan Orang Melalui Instrumen Hukum Nasional Dan Hukum Internasional DI Indonesia. Cendekia Hukum, Volume 3, no. 2, 2018, Page.22840;

Siti Rochmiyatun. Perdagangan Perempuan Perspektfi Yuridis. An Nisa'A, Volume 8, no. 1, 2013, Page.82-101;

Triana, Elly. Pola Komunikasi Interpersonal Korban Trafficking Pengantin Pesanan Di Singkawang Kalimantan Barat 7, no. April, 2009, Page.29-37;

Vyas, Atharva. Child Trafficking. International Journal of Trend in Scientific Research and Development, Volume-2, no. Issue-5, 2018, Page.1121-26;

Wulandari, Cahya, Sonny Saptoajie Wicaksono, Fakultas Hukum, and Universitas Negeri. Tindak Pidana Perdagangan Orang ( Human Trafficking ) Khususnya Terhadap Perempuan Dan Anak: Suatu Permasalahan Dan Penanganannya Di Kota Semarang. Yustisia, Edisi 90, 2014, Page.15-26;

Yenny AS, Henny Damaryanti. Perlindungan Hukum Terhadap Perempuan Dan Anak Korban Tindak Pidana Perdagangan Orang Melalui Modus Pengantin Pesanan, Volume 1, no. 1, 2020, Page.1-8; 